DOI: $10.14807 /$ ijmp.v2i1.26

\title{
APPLICATION OF PROJECT BASED LEARNING IN THE DISCIPLINE OF LOGISTICS: A CASE STUDY
}

\author{
Dn. Paulo César Chagas Rodrigues \\ Univ. Estadual Paulista (UNESP/FEG) - Brazil \\ E-mail: pauloccr@feb.unesp.br
}

Submission: $12 / 03 / 2011$

Accept: 23/04/2011

\begin{abstract}
Currently the higher education institutions need to search for new tools and methods to make learning more enjoyable and dynamic for students because the job market increasingly needs young people who have the ability to self-criticism above average. A search was performed on a course of action and technologist who had a total of 15 students, for the purpose of this research was to improve the learning level of students, reducing absenteeism and dropout, encourage research and participation in teamwork. As a way to develop this study the students had to develop a project of a bridge made of newspaper and involving the disciplines of logistics, financial management, human resource management and managing projects.
\end{abstract}

Palavras-chaves: project based learning; technologist; team; disciplines

\section{INTRODUÇÃO}

The application of the tool Project Based Learning (PBL) in the discipline of logistics in a course of technology was as a tool to support learning interesting.

It was observed that students had to leave the comfort zone, in which the candidate has the discipline and is concerned with learning. With the PBL students had to devote more time to learning, since the end of the semester they were required to produce a design that is feasible.

We also observed that PBL allows the application of multidisciplinary projects, ie, the project was for the discipline of logistics, but they had to worry about observing and studying mathematical finance (cost), human resource management and project management. 
DOI: $10.14807 /$ ijmp.v2i1.26

The objective of this research is to improve the level of student learning, reduce absenteeism, and encourage research and participation in team work. This is an action research, in which he sought to create a new dynamic of class, with new evaluation metrics and allowing interference in the regulatory discipline in the course of technology.

\section{PROJECT BASED LEARNING}

Venville, et al. (2000) in their case study that focused on three pairs of students who work together in an integrated mathematics and science project, found that student learning was enhanced as a result of collaboration and communication among peers. Students were able to research in mathematical sciences and relevant concepts that were sometimes beyond the expertise of the teacher. In addition, the students developed ideas for further research and studies, as a result of the project team.

Project Based Learning (PBL) is an effective educational approach. It focuses on creative thinking, problem solving, and interaction with fellow students to create and use new knowledge. Notably, this is done in a context of dialogue, active science with supervisors who are active researchers (BERENFELD, 1996; MARCHAIM, 2001).

The point, then, PBL is to reverse this relationship: engage students in real-world projects through which they learn the math and science formulas and laws on which our world is increasingly built. No matter whether the schools have low achievement of students or students with high yield, a high percentage of students find that working with real-world projects to be exciting, engaging, fun, fulfilling and meaningful. And, research indicates (SCHNEIDER et al., 2002) that by this method, they learn at a deeper level (and not learning at a deeper level is one of the weaknesses of our national education system (DART et al., 1999; TOBIN; GALLAGHER, 1987) to learn from our traditional teaching methods. Thus, we see PBL as one of powerful tools that educators can use in classrooms to increase equity and excellence in education worldwide.

According to Asan and Haliloglu (2005), in PBL the teacher acts as facilitator in designing activities and providing resources and advice to students. 
DOI: $10.14807 /$ ijmp.v2i1.26

Students collect and analyze information, make discoveries, and communicate their results. Projects are often interdisciplinary, with teams of various sizes and in different locations work on projects. Instruction and facilitation is guided by a broad range of teaching objectives. PBL provides an environment of trust in which teachers can help students increase their skills through cooperative learning and collaboration in solving problems.

According to Chen and Chen (2007), the growing popularity of PBL can be found in some polls, including the study of science and mathematics learning, multimedia production (LIU, HSIAO, 2001; LIU, 2003; YANG, 2003), Principles Design of PBL (BARRON et al., 1998), motivation (Blumenfeld, et al, 1991; CHEN; MCGRATH, 2003), collaborative learning (DAY, LOU; VAN SLYKE, 2004; HARGIS, 2005; MARCHAIM, 2001) online community of students (MURPHY, GAZI, 2001), and professional development services for teachers (FRANK; BARZILAI, 2004; ROSENFELD, BEN-HUR, 2001; Toolin, 2004).

\section{ESTUDO DE CASO}

This case study was conducted in a tertiary institution, located in the state of Sao Paulo in a course of higher technological level, this study lasted 6 months.

The course was held in which the research is the technology in sugarcane production, which had approximately 15 students enrolled in the semester and had about 8 courses.

Of the eight courses taught in the semester were chosen disciplines of logistics, financial management, human resource management and project management, since they had a curriculum that could be chained.

The logistics discipline has served as the basis for the practice of PBL, because this subject had a load of 4 hours per week, and it might occur interdisciplinary between the other three disciplines.

The project developed by the students was to build a bridge of paper on which they should do cost assessment and feasibility, this project they had to define how the bridge would be built, what factors might affect the same, size, 
DOI: $10.14807 /$ ijmp.v2i1.26

but watching width $\mathrm{x}$ length $\mathrm{x}$ height to end and that supports the weight of a book.

In Figure 1 gives an outline of how the bridge would be, not being students of civil engineering, was not given emphasis on the specific aspects, but it would be easy to achieve the goals.

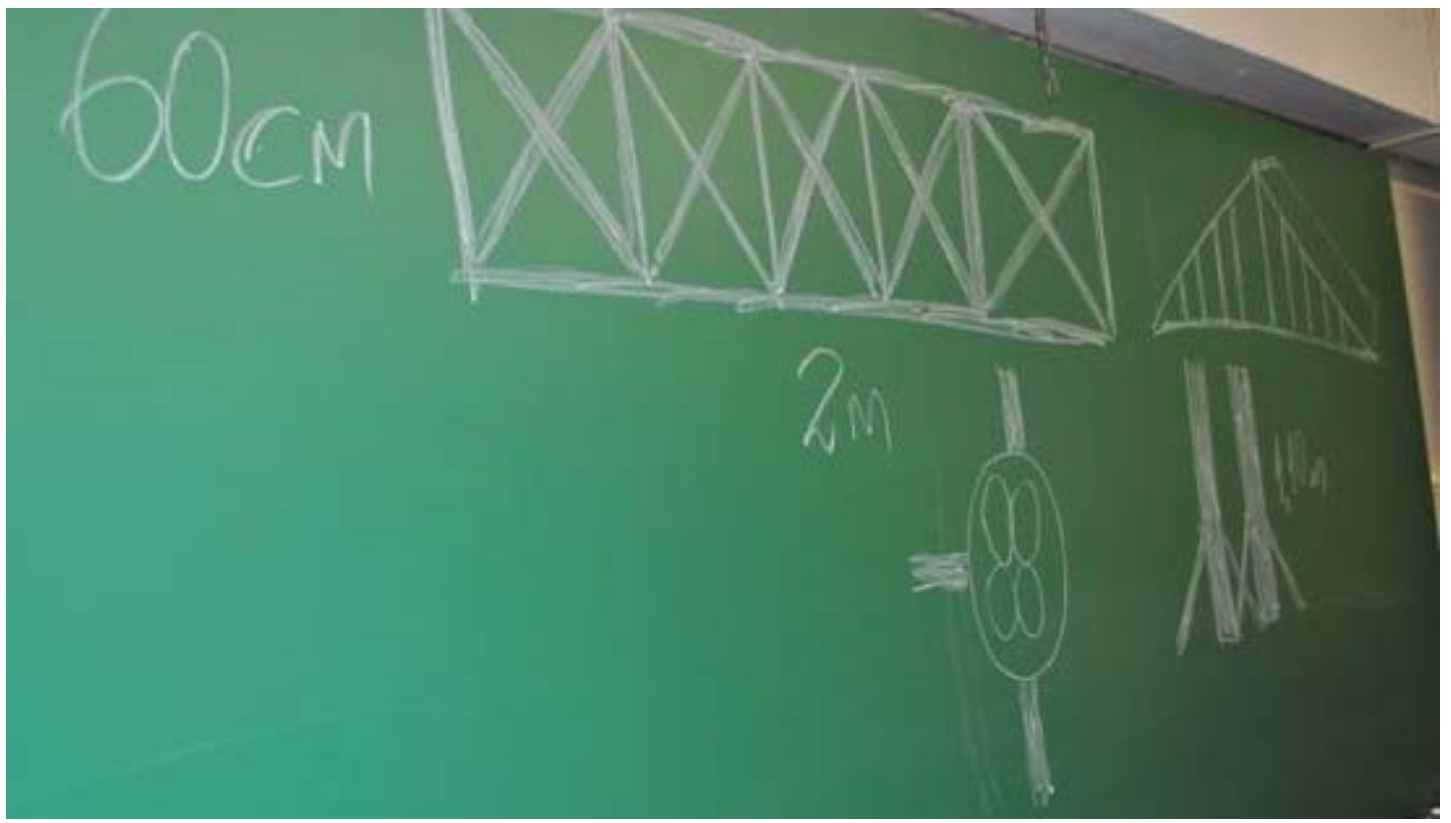

Illustration 1: Sketch of how the bridge would be constructed of newspaper

The project began with a PBL curriculum restructuring of the disciplines involved, was proposed in which a larger load of theoretical and practical component to support the project.

In the practical component could be defined as a project, building a bridge of paper on which students with the support of the teachers involved had to create the schedule for implementation, with the costs and criteria for evaluating performance of those involved, this review occurred weekly and was 360.

Since the theoretical component allowed to support PBL, through the theories that each discipline had to teach, only in condensed form and to allow students to apply during the project, was also set a time to support questions, which was not included in the timetable. The workload for each subject was divided according to Table 1. 
DOI: $10.14807 /$ ijmp.v2i1.26

Table1: disciplines and their division between the components

\begin{tabular}{|l|r|r|r|}
\hline \multicolumn{1}{|c|}{ Discipline } & \multicolumn{1}{c|}{$\begin{array}{c}\text { Practical } \\
\text { Component (hs) }\end{array}$} & \multicolumn{2}{c|}{$\begin{array}{c}\text { Theoretical } \\
\text { Component (hs) }\end{array}$} \\
\hline Logistics & 2 & 2 & 0 \\
\hline Financial Management & 1 & 0 & 1 \\
\hline Human Resource Management & 2 & 1 & 1 \\
\hline Project Management & 1 & 1 & 0 \\
\hline
\end{tabular}

During the PBL were involved all 15 students, which had distinct roles within the team in some individual cases, but were running everywhere and practice together in a cohesive manner.

We divided the students into three teams of five students who worked three areas of competence of the logistics, they are: logistics supply, production and distribution. Within each area, they had to worry about doing the survey cost, integration of team members, lead-time process, compliance with the requirements of the project, among other factors.

As for the evaluation of students was given weights for each subject as the components and processes that made up the PBL. Table 2 can be seen these criteria.

Table 2: Distribution of the evaluation of PBL

\begin{tabular}{|l|c|c|c|c|}
\hline \multicolumn{1}{|c|}{ Variables } & \multicolumn{4}{c|}{ Evaluation } \\
\hline & Theoretical & Practical & Support & $\begin{array}{c}\text { Assessment } \\
360^{\circ}\end{array}$ \\
\hline Logistics & $\mathbf{0 , 2 0}$ & $\mathbf{0 , 5 0}$ & $\mathbf{0 , 1 0}$ & $\mathbf{0 , 2 0}$ \\
\hline Financial Management & $\mathbf{0 , 3 0}$ & $\mathbf{0 , 3 0}$ & $\mathbf{0 , 2 0}$ & $\mathbf{0 , 2 0}$ \\
\hline Human Resource Management & $\mathbf{0 , 2 0}$ & $\mathbf{0 , 2 0}$ & $\mathbf{0 , 1 0}$ & $\mathbf{0 , 5 0}$ \\
\hline Project Management & $\mathbf{0 , 3 0}$ & $\mathbf{0 , 3 0}$ & $\mathbf{0 , 2 0}$ & $\mathbf{0 , 2 0}$ \\
\hline & & & & \\
\hline
\end{tabular}

The theoretical evaluation was divided into two parts, the first with a written test on the whole the theory exposed in the classroom and the second based on reports prepared by them, where they had to expose all the details about the processes, this evaluation was applied orally as a team and then individually.

\section{CONSIDERAÇÕES FINAIS}

It was observed that interdisciplinary with this class proved fruitful, as the students began to understand the purpose of each discipline in the course, there was also a greater cohesion among the subjects who participated in the PBL, we observed the need for uniformity plans and classroom teaching. 
Independent Journal of Management \& Production (IJM\&P)

v. 2, n. 1, January - June 2011

ISSN: 2236-269X

DOI: $10.14807 /$ ijmp.v2i1.26

Part practices introduced by PBL, proved adequate to the needs of the course of a technologist, because students must have a greater burden in relation to practice and should have a theoretical understanding on the application of scientific theories in everyday organizations.

It might be considered more specifically in this course subjects can be grouped to allow over the course of the academic years students have to develop phases of PBL.

It was observed that the students had a better utilization, increased selfesteem, the critical view about the processes running on the day-to-day organizations.

This being studied curriculum change of this course, with the inclusion of PBL as a primary stage, so there should be greater monitoring of students in the first year course.

\section{REFERENCES}

ASAN, A.; HALILOGLU, Z. Implementing Project based learning in computer classrom. The Turkish Online Journal of Educational Technology, v. 4, n. 3, p. 68-81, 2005.

BARRON, B. J.; SCHWARTZ, D. L.; VYE, N. J.; MOORE, A.; PETROSINO, A.; ZECH, L.; BRANSFORD, J. D. Doing with understanding: Lessons from research on problem- and project-based learning. Journal of Learning Sciences, v. 7, n. 3, p. 271-311, 1998.

BERENFELD, B. Linking Students to the Info-sphere. Technology Horizon in Education Journal, v. 23, p. 76-84, 1996.

BLUMENFELD, P. C.; SOLOWAY, E.; MARX, R.; KRAJCIK, J. S.; GUZDIAL, M.; PALINCSAR, A. Motivating project-based learning: Sustaining the doing, supporting the learning. Educational Psychologist, v. 26, n.3, p. 369-398, 1991.

CHEN, P.; CHEN, H. L. Knowledge building and technological dynamics in an online project-based learning community. International Journal of Technology in Teaching and learning, v. 3, n. 2, p. 1-16, 2007.

CHEN, P.; MCGRATH, D. Moments of Joy: Student Engagement and Conceptual Learning in the Design of Hypermedia Documents. Journal of Research on Technology in Education. V. 35, n. 3, p. 402-422, 2003.

DART, B.; BURNETT, P.; BOULTON-LEWIS, G.; CAMPBELL, J.; SMITH, D.; MCCRINDLE, A. Classroom learning environments and students' approaches to learning. Learning Environments Research, v. 2, n. 2, p. 137-156, 1999. 
DOI: $10.14807 / \mathrm{ijmp} . v 2 \mathrm{i} 1.26$

DAY, J.; LOU, H.; VAN SLYKE, C. Instructors' experiences with using groupware to support collaborative project-based learning. Distance Education Technology, v. 2, n. 3, p. 11-25, 2004.

FRANK, M.; BARZILAI, A. Integrating alternative assessment in a project based learning course for pre-service science and technology teachers. Assessment \& Evaluation in Higher Education, v. 29, n. 1, p. 41-61, 2004.

HARGIS, J. Collaboration, community and project-based learning- Does it still work online? International Journal of Instructional Media, v. 32, n. 2, p. 157161, 2005.

LIU, M. Enhancing learners' cognitive skills through multimedia design. Journal of Interactive Learning Research, v. 11, n. 1, p. 23-39, 2003.

LIU, M.; HSIAO, Y. Middle school students as multimedia designers: A projectbased learning approach. Journal of Interactive Learning Research, v. 13, n. 4, p. 311-337, 2001.

MARCHAIM, U. High-school Student Research at Migal Science Institute in Israel. Journal of Biological Education, v. 35, n. 4, p.178-182, 2001.

MURPHY, K. L.; GAZI, Y. Role plays, panel discussions and simulations:

Project-based learning in a Web-based course. Education Media

International, v. 38, n. 4, p. 261-270, 2001.

ROSENFELD, S.; BEN-HUR, Y. Project-based learning (PBL) in science and technology: A case study of professional development. Science and Technology Education: Preparing future citizens, v. 1, p. 31-37, 2001.

SCHNEIDER, R. M.; KRAJCIK, J.; MARX, R. W.; SOLOWAY, E. Performance of students in project-based science classrooms on a national measure of science achievement. Journal of Research in Science Teaching, v. 39, n. 5, p. 410-422, 2002.

TOBIN, K.; GALLAGHER, J. J. What happens in high school science classrooms? Journal of Curriculum Studies, v. 19, n. 6, p. 549-560, 1987.

TOOLIN, R. E. Striking a balance between innovation and standards: A study of teachers implementing project-based approaches to teaching science. Journal of Science Education and Technology, v. 13, n. 2, p. 179-187, 2004.

VENVILLE, G.; WALLACE, J.; RENNIE, L.; MALONE, J. Bridging the Boundaries of Compartmentalized Knowledge; Student Learning in an Integrated Environment. Research in Science \& Technological Education, v. 18, p. 23-35, 2000.

YANG, S. C. Computer-mediated history learning: spanning three centuries project. Computers in Human Behavior, v. 19, p. 299-318, 2003. 